\title{
La ricostruzione storica della città attraverso l'iconografia urbana. Il caso studio di San Giovanni d'Acri
}

\author{
Cecilia Maria Roberta Luschi \\ Laura Aiello
}

Abstract

La ricostruzione storica dell'immagine di una città attraverso l'iconografia, rappresenta una delle pietre miliari della ricerca della storia urbana, appare tuttavia evidente che lo studio dell'iconografia urbana negli ultimi trenta anni si sia svincolata da tale sussidiarietà per raggiungere la dignità di uno spazio autonomo nel campo della ricerca. La rappresentazione grafica rappresenta un potente mezzo espressivo che nei secoli ha permesso di lasciare tracce di grande valore documentario. La città di Akko, individuata come caso studio, ha una ricca 'iconografia urbana che concede numerosi spunti di riflessione oggetto di continui studi e aggiornamenti nei differenti settori di ricerca aprendosi ad un approccio interdisciplinare. L'interesse per tale città è sicuramente da attribuire a un rinnovato interesse verso il sito che dal 1972 viene incluso negli elenchi del patrimonio culturale mondiale UNESCO. Significativa l'opera di Kesten che nel 1993 si preoccupa di raccogliere i diversi studi di settore, offrendo alla modernità un quadro dello stato dell'arte su cui ancora oggi archeologi, storici e architetti si confrontano alla luce dei continui ritrovamenti archeologici che confermano o confutano le differenti ricostruzioni. II presente contributo offre in tale ambito una narrazione mirata delle principali cartografie e vedute storiche, attraverso l'analisi dei codici della rappresentazione e l'identificazione degli organismi architettonici più rappresentativi della città.

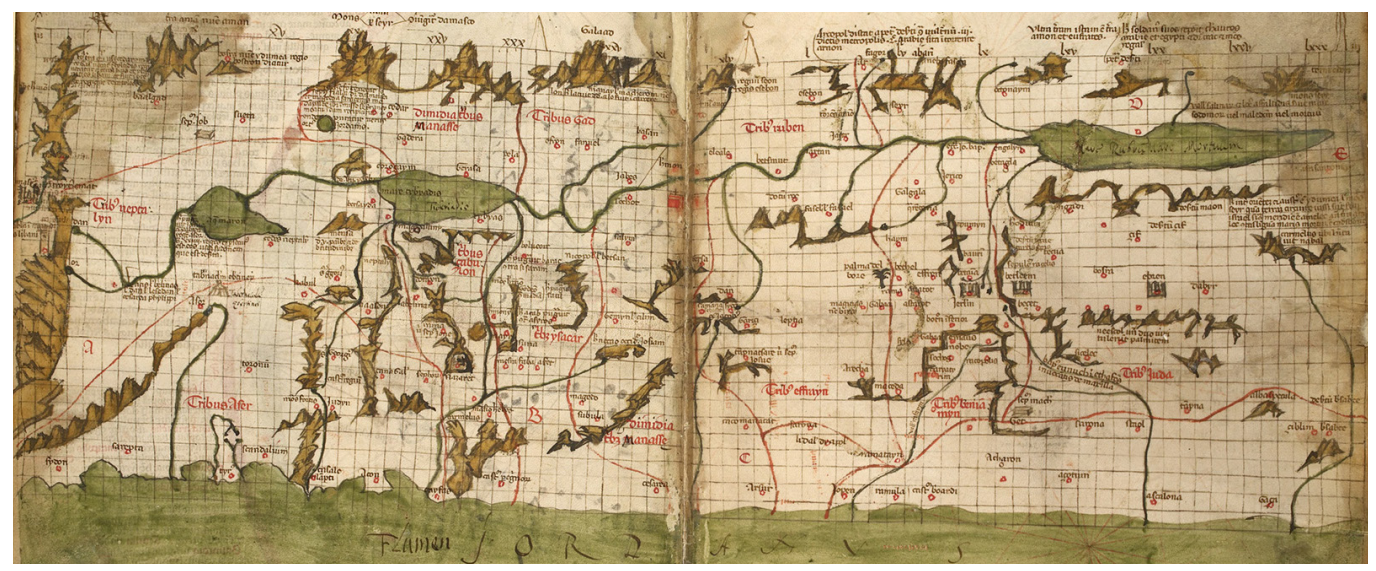


La città ha da sempre rappresentato un organismo complesso e dinamico la cui forma rappresenta la sintesi espressiva di numerosi fattori: esigenze abitative di natura individuale e collettiva, idee sociali, religiose, economiche, politiche o ricreative a cui nei secoli i molteplici assetti sociali hanno dato soluzioni diverse.

Volerne ricostruire l'immagine attraverso la lettura delle fonti iconografiche significa quindi attuare una lettura filologica che passi attraverso una conoscenza approfondita dei meccanismi evolutivi attuati dalla cultura che l'ha prodotta e giungere ad interpretare i codici della rappresentazione adottati per la redazione del documento. Da sempre, voler fornire l'immagine di un luogo, rappresenta un'azione soggettiva che strutturandosi su un linguaggio codificato, deve necessariamente piegarsi ad un'azione discretizzante del soggetto che intraprende l'opera, sia esso un cronista, o uno specialista di settore (geografo, militare, vedutista, miniaturista, eccetera). In tale ambito la rappresentazione iconografica diviene una fonte diretta di straordinaria efficacia. Essa offre in pochi attimi molti più dati di quanti ne possa offrire una descrizione narrativa portando in sé un apparato di informazioni di cui non sempre se ne ha assoluta contezza. La codificazione dei codici rappresentativi inquadra quindi una fase di studio rilevante che se condotta correttamente permette di catalogare una serie di informazioni altrimenti perdute, ed è in tale ambito che si inserisce il presente studio con il fine di alimentare quel dibattito interdisciplinare necessario a innescare i processi di conoscenza perseguiti.

La considerevole varietà di rappresentazioni della città di Akko, permette oggi di avere una visione di insieme storica articolata. Ogni aspetto specifico, ogni tema, affrontato dai differenti autori partecipa alla ricomposizione di un quadro in cui $\mathrm{i}$ vari elementi offrono un'immagine ricca e complessa.

Una delle carte più antiche e dibattute, in cui è possibile rintracciare la città di Akko, è la Tabula Peutingeriana della quale ci perviene una copia del XII-XIII secolo ad oggi conservata presso la Hofbibliothek di Vienna e derivante da una più antica che riportava le vie militari dell'Impero Romano. La città di Akko appare con il nome di Ptolemaide ed è posta a XXXII miglia da Tiro e XX da Thora (l'odierna Zikhron Ya'agov, nei pressi della più nota Cesarea). Grazie agli studi condotti [I] possiamo oggi affermare che la rappresentazione del sito rientra nella tipologia di vignetta a 'doppia torre', iconologia comune a sei varianti. Anche se non vi è al riguardo una univoca interpretazione da parte degli studiosi, rileviamo in tale sede che sia che si tratti di una villa fortificata con torri, di cui dubitiamo, sia che si tratti di una posta sul cursus publicus, la città di Ptolemaide non è comunque collocata sulla linea di costa ma nell'immediato entroterra, dove si ritiene sia il tracciato originale della via Maris. Ubicazione, questa, che concorderebbe con i ritrovamenti sul Tel di Akko dell'insediamento antico (fig. I).

Fig. I. Estratto da: Conradi Milleri Editio, Tabula Peuntingeriana (ca. 250), in Ravensburg, 1887/88, digitalizzata da Biblioteca Augustana. La rappresentazione procede per vignette e rappresentazion topologiche e simbolico ideogrammatiche.

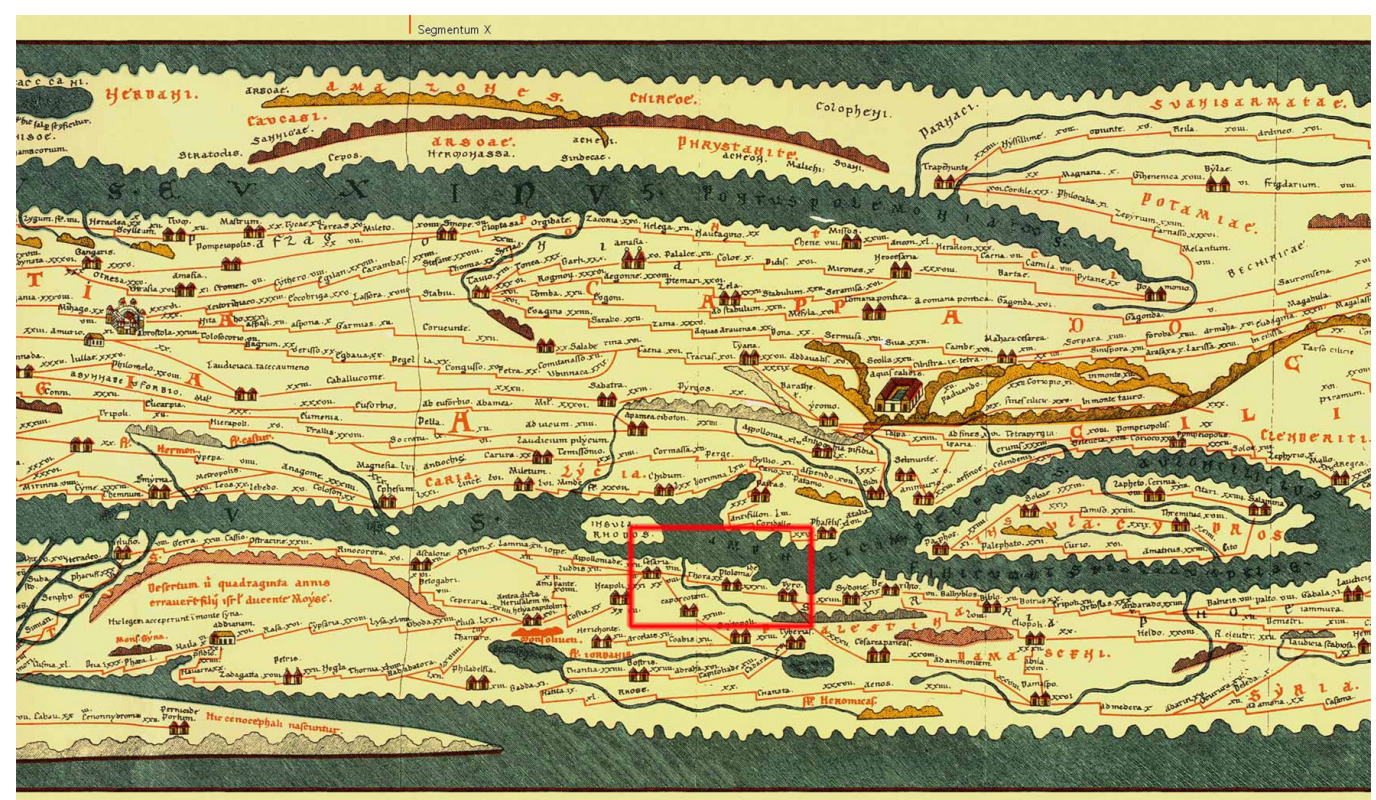


Di particolare valore appare la descrizione di Matthew Paris che oltre ad offrire un testo descrittivo, correda la sua Cronica Majora [2] di una carta della Terra Santa in cui la città di Akko assume un ruolo centrale per proporzioni in rapporto al territorio. Disponiamo attualmente di due copie molto simili della suddetta carta, conservate a Cambridge e a Londra (fig. 2). Analizzando la redazione di queste, la prima osservazione rilevante riguarda proprio l'estensione che viene dedicata alla rappresentazione della città. Essa occupa la parte centrale e investe un'area di valenza primaria, specie se confrontata con le città di Gerusalemme e di Tiro, entrambe rappresentate secondo modeste estensioni. Ciò è certamente da attribuire all'importanza politica che doveva avere Akko all'epoca della stesura della carta. La città, dopo la caduta di Gerusalemme nel I |87, fu infatti capitale del Regno Latino dal | |9| al |29|. La rappresentazione di Paris è una mappa ideogrammatica delle gerarchie edilizie che connotavano i luoghi di potere della città, priva di parametri di carattere mensorio o proporzionale, il cui codice sembra ancora oggi essere leggibile. Infatti analizzando le due stesure è possibile osservare la reciproca congruenza pur riscontrando alcune singolarità nella scrittura dei nomi, questa sembra rivelare una differente derivazione etimologica, per esempio la vile e la cite, che potrebbe indicarci due differenti estensori delle carte.

Non potendo apprezzare la differenza del tratto del disegno o la consistenza della tecnica grafica, possiamo però annotare che in entrambe le rappresentazioni (fig. 2) la cinta principale include nel limite superiore (ad est) una porta posta in direzione di Damas [3], Damasco

Fig. 2. Matthew Paris, Chronica Majora, Itinerary to the Holy Land. Confronto delle due copie datate 1240- 1253. In alto (a) la copia di Cambridge Corpus Christi College Library, MS 26, fiii v-iv ri in basso (b) la copia di In basso (b) la copia di Londra (c) British Library Segnatura: Royal MS 14 clla cittì di Akko appe della città di Akko appare molto più ampia se comparata a quelle delle grandi città rappresentate nella stessa carta. La

rappresentazione include una breve descrizione letteraria e la toponomastica è affiancata da disegni descrittivi dell'intera città che offrono una narrazione che procede per paratassi poggiante sugli edifici principali.
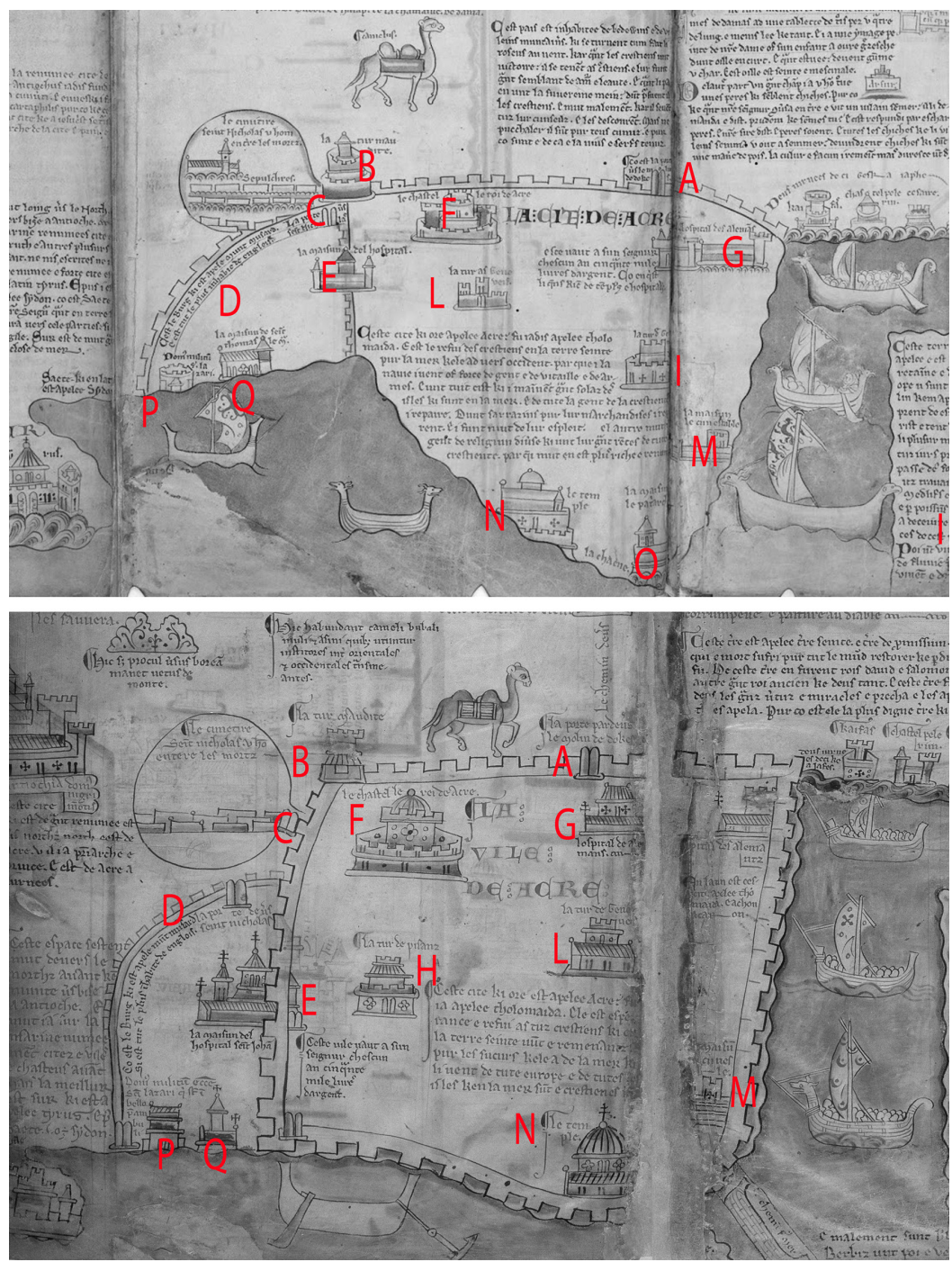
(A); procedendo in senso antiorario si intercetta la tur maudite, la torre maledetta (B), dove le mura prendono una piega est-ovest; In direzione ovest si apre la porta di collegamento con le cimetire Sñt Nicholas, il cimitero di San Nicola (C) e, ancora più avanti, una nuova porzione di mura si dirama a nord dal limite della città (D) perimetrando un borgo denominato mũt (monte) mufard, che secondo la descrizione era le plus îhabite de englois. Tra gli edifici della prima cinta riconosciamo l'ospital de alemans, l'ospedale degli alemanni, a nord est (G); la maisun des hospital sñt Joha, la casa degli Ospedalieri, a cavallo delle mura interne (E); le chastel le roi de Acre, il castello del re di Acri, a Nord (F); la tur de pisanz, la torre dei pisani, al centro della sola carta di Londra $(H)$, fronteggiata a sud est dalla torre dei veneziani, la tur de vene [****] $(\mathrm{L})$. Complementare alla torre dei pisani, nella carta di Cambridge si ritrova la tour S. Gr[**** . Riconosciamo inoltre le temple, il tempio (N), rappresentato in entrambe le carte come un edificio cupolato e la maisũ du cunestable, la casa del connestabile lungo la costa (M); Nella carta di Cambridge rileviamo una singolarità: fra il tempio e la casa del connestabile si innesta un edificio denominato la maison le patard $(O)$, che, dato il richiamo del toponimo ad una valuta antica, potremmo spingerci a identificare come la dogana del porto. Nelle immediate vicinanze viene annotata la dicitura la chaene, la catena, elemento riportato nelle diverse cronache di pellegrinaggio [4], che chiudeva il porto stesso. Altri due edifici si attestano nell'area di mont mufar, il primo, di tipo militare, costruito a ridosso del perimetro murario, Dom militu ecce Sĩ Lazari $(P)$ e, da quanto è possibile leggere sulla carta di Cambridge, la maison de seĩt Thomas le $m$ (Q). Entrambe le rappresentazioni redatte tra il I 240 e il I 253 descrivono anche un'intensa attività navale che seppur non disegnata nei suoi caratteri principali, viene descritta secondo lo schieramento delle navi rappresentate. Quelle nel porto sono disposte perpendicolarmente alla costa (a destra del disegno) mentre quelle in navigazione sono raffigurate di cabotaggio. Ciò è interessante perchè nella stesura del I240- 1243 del portulano pisano Lo compasso da navigare [5], ritrovato ad Alghero, viene descritto l'approccio al porto di Akko che sembra poter attagliarsi a quanto rappresentato dal Paris.

Di altra natura invece è la rappresentazione fatta dal Vesconte [6] un sessantennio dopo, a questi anni è databile la sua cartografia compresa all'interno della raccolta Secreta Fidelium Crucis del Torsello [7]. Anche in questo caso disponiamo di due diverse stesure della solita mappa, una conservata ad Oxford e l'altra a Londra, realizzate con materiali e colori congruenti fra loro, con riferimenti toponomastici pressoché identici, ma con una differenza nella rappresentazione grafica: nella prima, rispetto a quella di Londra, gli edifici vengono infatti raffigurati anche nel risvolto della pianta di copertura, offrendo una qualche approssimativa indicazione volumetrica [8].

Queste mappe hanno avuto una significativa importanza per quanti, più recentemente, si sono occupati di individuare i luoghi crociati. II raffronto con la carta del Paris permette di confermare i rapporti di reciprocità dei principali acquartieramenti: la giustapposizione del quartiere pisano e del quartiere veneziano $(\mathrm{H}-\mathrm{L})$, diretti interessati dell'area portuale; la posizione dell'ospedale $(\mathrm{E})$ a ridosso delle mura est-ovest e poco più a est quella del castello (F). Si riconferma la posizione degli alemanni (G) a ridosso del circuito murario est della città in cui il Paris collocava la via per Damasco (A). Meno chiara invece è l'effettiva possibilità di identificare la casa del connestabile individuata dal Paris (M) con l'arsenale (M?) individuato dal Vesconte, posti entrambi lungo le coste a sud del quartiere veneziano (L). Rimane invariato il toponimo della torre maledetta posta nell'angolo del primo circuito murario (B) (fig. 3).

Una fase evolutiva intermedia tra la carta del Vesconte e il riconoscimento moderno delle emergenze architettoniche ci viene offerta dalla veduta della città della fine del XVII secolo di Gravier d'Ortières [9]. La veduta appare dominata dalla presenza di imponenti rovine(fig. $5)$ secondo una panoramica dal mare verso la città. I resti della possente chiesa gotica del sant'Andrea $(X)$, caratterizzano l'estremo promontorio a mare.

Effettuando una ricognizione di tutte le carte, si possono identificare con una certa affidabilità gli edifici che nei secoli successivi hanno continuato a costituire la struttura urbana di Akko che ancora oggi possiamo rintracciare fra ritrovamenti archeologici o rimanenze parziali degli elevati. Nello specchio d'acqua che lambisce la città si stagliano i resti del porto 
Fig. 3. Vesconte, Civitas Acon sive Ptolomaida, in Digital Collection by the British Library, Londra. Le lettere corrispondono ai principali edifici

riconosciuti nella carta del

Paris Si tratta di cana de presenta una planine completa della città

puntualizzata dagli edifici principali disegnati negli alzati con loro precipue caratteristiche.

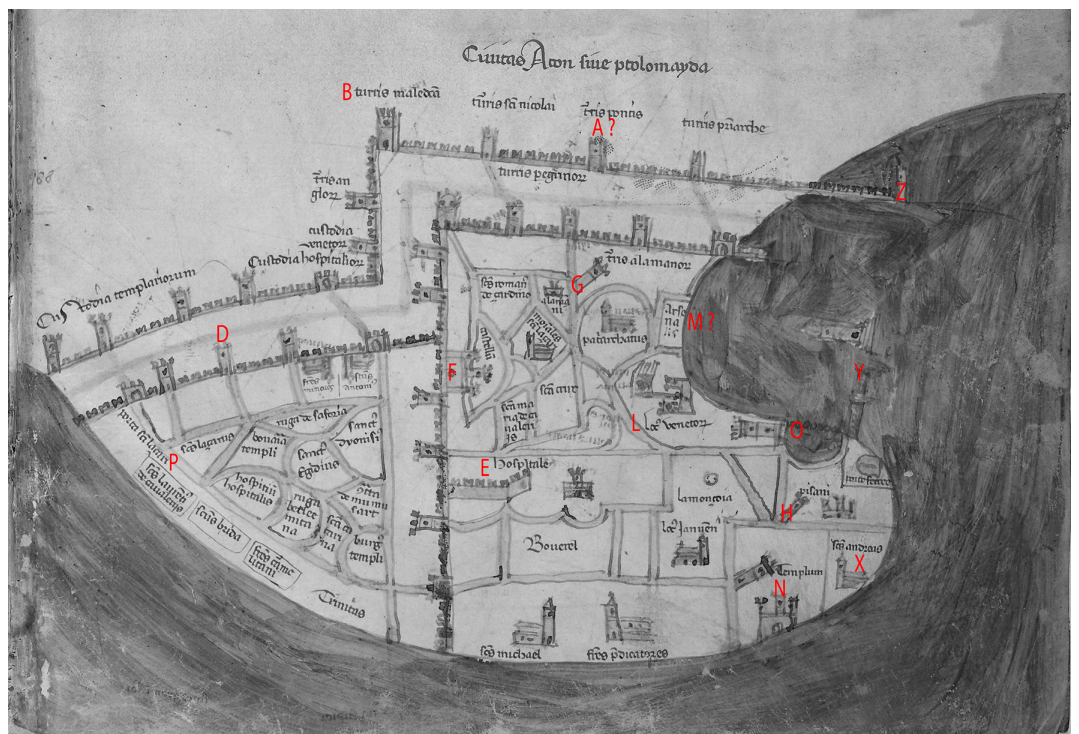

(Y) che continua ad accogliere al suo interno alcune imbarcazioni. Procedendo nell'analisi della veduta di Gravier, muovendoci da sinistra verso destra, si sviluppa una cortina di bassi edifici dal tetto piano, fino a intercettare una costruzione prospiciente la costa e coperta dalla tipica cupola delle moschee, probabilmente corrispondente all'attuale moschea di Sinan Basha. Se la lettura condotta è corretta, è possibile identificare (a sinistra di questa) le rovine del convento domenicano su cui sarà edificato nel 1785 il Khan el-Undan. Sulla destra una scritta riporta Palais du grand maitre, ad indicare una poderosa costruzione collocata prospetticamente sullo sfondo della scena. Volendo azzardare un parallelismo potremmo identificare tale edificio con ciò che il Vesconte individuava con il termine 'il castello', ovvero l'attuale cittadella. Un'imponente torre potrebbe essere identificata con l'attuale torre del burj al-Sultan e andando a ritroso con l'Arsenale della carta del Vesconte (M?). Tre arcate sembrano ricalcare il sito dell'ex convento delle clarisse su cui sorge l'attuale Khan a-Shawarda. La veduta del I685, propone una realistica immagine di Akko, ormai pressoché abbandonata e in rovina.
Fig. 4. Picart (incisore), Civitas Acon sive Ptolomaida, 1630.The Eran Laor Cartographic Collection of the National Library of Israel. Mappa della città caratterizzata da una legenda referenziata e dalla rappresentazione in pseudo assonometria degli alzati magriormente curati per gli edifici eminenti.

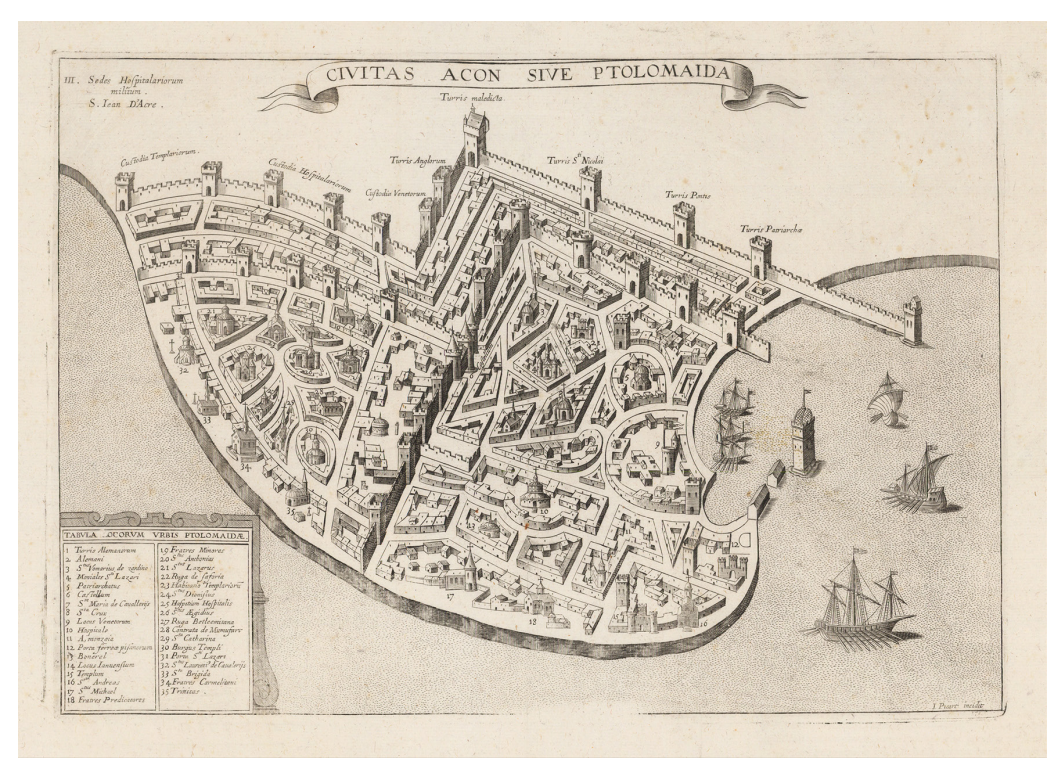


Fig. 5. Étienne Gravier, ve de Saint-jean d'Acre, 685-1687, Bibliothèque Nationale de France, département Cartes et plans, GE DD-226 ( 14 RES). Le lettere in rosso corrispondono ai principali edifici riconosciuti nella carta del Vesconte. Si tratta di una veduta da Mare verso la città dove viene operata una gerarchizzazione, in relazione alle dimensioni, degli edifici più importanti.
È interessante osservare come la carta del Picard del I630, recuperi nella sua rappresentazione della Civitas Acon sive Ptolemaida una immagine presumibilmente ormai non realistica della città. Egli sembra riferirsi a diverse fonti iconografiche, in primis il Vesconte, il cui rifermento è dichiarato dallo stesso autore, la seconda, meno accreditata, potrebbe essere proprio il Paris. Picard infatti struttura un'assonometria basata sulle carte del Vesconte e aggiunge nuovamente l'attività navale all'interno del porto di Akko che in maniera complementare compariva nelle carte del Paris.

Secondo una visione più ampia che tenga insieme aspetti multidisciplinari, in merito a ciò vorremmo ulteriormente osservare che Pisa vantava sul porto di Akko il diritto di catena, informazione confermata dal relativo portulano che descrive esattamente le manovre da effettuare per accedere al porto; di contro evidenziamo che il Vesconte è un cartografo della repubblica di Genova ed il Torsello è invece veneziano. Le appartenenze geo-politiche quindi chiariscono il perché del mutismo delle carte sull'attività navale se espresso dalle repubbliche marinare che non hanno possibilità di entrarvi se non condotti da addetti pisani. Ecco come, in un continuo passaggio dallo studio del particolare allo studio generale del contesto, che recuperi peculiari input esplicativi dei dettagli descrittivi, si riesca a sviluppare nuove tracce di ricerca inesplorate. L'iconografia urbana nella sua autonomia offre importanti riflessioni sul riconoscimento dei luoghi e la sua interazione con i differenti campi di ricerca permette ancora oggi di svelare nuove chiavi di lettura dei codici della rappresentazione adottati (si pensi alla presenza delle imbarcazioni e al modo di rappresentarle).

Nel presente caso, in una lettura di più ampio respiro, le osservazioni condotte ci aprono nuove tracce di ricerca capaci di chiarire molto meglio sia come accedere al porto, analizzando anche il Compasso da navigare pisano, sia identificare in modo molto più preciso la posizione dei vari monumenti rappresentati nella veduta e referenziati rispetto alla moderna immagine urbana. Lo studio è rivolto a fornire dati sempre più coerenti e credibili riguardo la città moderna che deve porre in essere azioni di salvaguardia e recupero del proprio Cultural Heritage ma che ancora non ha chiara tutta la struttura storica e la sua stratificazione.

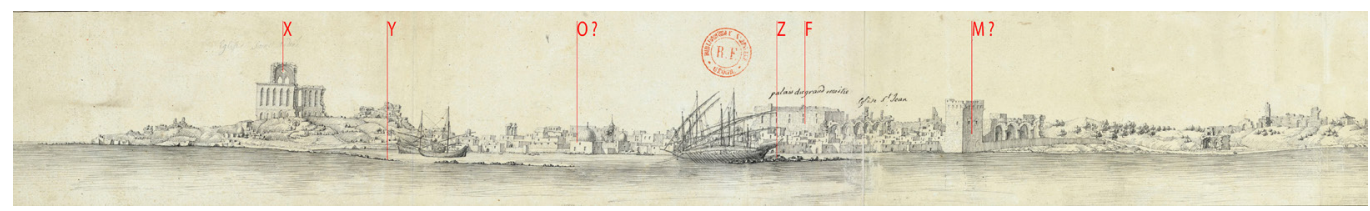

\section{Note}

[I] Si veda: Bosio 1983, p 109; Carli 20 I3, pp. 7-25

[2] Paris, I872-I880 (1259). Per la prima volta la Cronica fu resa pubblica nel 1259 e ciò che vi si trova dentro, dice lo stesso Paris, è materiale che va dal I240 al I253. I primi due volumi del manoscritto si trovano al Corpus Christi College di Cambridge, il terzo è annesso alla sua Historia Anglorum, conservata nella British Library di Londra. Gran parte dell'opera è stata resa pubblica tramite la digitalizzazione online ad opera della British Library.

[3] Dove non diversamente specificato, il nome riportato si riferisce al toponimo indicato sulla carta di Londra.

[4] Si veda: Sanudo, 1972 (I32I), nº 66; DiVitry (I226) in De Sandoli, I983,Vol. III, p. 307.

[5] Debanne 20। I.

[6] Oggi è possibile visualizzare gli originali grazie al lavoro di digitalizzazione della British Library di Londra. La collezione include: una mappa del mondo, Mappamundi, disegnata nello stile di una carta nautica, cinque carte nautiche portolane delle coste dell'Europa e del nord Africa, una carta riassuntiva dell'Europa dell'est e una mappa della Terra Santa.

[7] Sanudo, I972 (I32 I). L'opera fu stampata in più copie nel I6 I I ad Hannover nell'edizione di Jaques Bongars; alcune copie dei manoscritti originali sono oggi conservate a Firenze, Londra e Parigi.

[8] Tale elemento sarà ripreso e sviluppato nelle riedizioni seicentesche e in particolare nell'incisione Picard del 1630 che arriverà ad apparecchiare una vista assonometrica della città, offrendo alla rappresentazione degli edifici la forma volumetrica accennata nelle pseudo assonometrie delVesconte.

[9] Étienne Gravier, Vue de Saint-Jean d'Acre, 1685-1687, Bibliothèque Nationale de France, département Cartes et plans, GE DD-226 (I 4 RES). 


\section{Riferimenti bibliografici}

Bosio Luciano (1983). La Tabula Peutingeriana. Una Descrizione Pittorica del Mondo Antico. Rimini: Maggioli Editore.

Cardini Franco (1933). Studi sulla storia e sull'idea di Crociata. Roma: Jouvence.

Cardini Franco (197I). Le crociate: tra il mito e la storia. Roma: Istituto di cultura nova civitas.

Carli Olivia Sara (20I3). Le 'Vignette' della Tabula Peutingeriana. In Calandra di Roccolino Giacomo, Carli Olivia Sara (a cura di) Antichità immaginate. Engramma 106 maggio 2013.

Cristea Ovidiu (2002). La suprématie maritime à la fin du XIlle siècle:un point de vue de Marino Sanudo Torsello. In Annuario Istituto Romeno di cultura e ricerca umanistica, 4, 2002

De Sandoli Sabino (1983). Itinera Hierosolymitana Crucesignatorum, Vol. III. Jerusalem: Franciscan Printing Press.

Debanne Alessandra (20I I). Lo Compasso de navegare. Edizione del codice Hamilton 396. Bruxelles: Peter Lang.

Fanucci Giovanni Battista (I 8|7). Storia dei tre celebri popoli marittimi dell'Italia. Veneziani, Genovesi, Pisani. E delle loro navigazioni e commerci nei bassi secoli, libro III. Pisa: Francesco Pieraccini editore, pp. 3-7.

Kesten Alex (1993). The old city of Acre. Re-examination report 1993. Acre: Printed by the survey of Israel.

Luschi Cecilia Maria Roberta (2018). Among the archaeologists and the designers: a critical survey of Sant'Andrea of Acre in Israel. In Czasopismo Techniczne, 2018,Vol.I I.

Mariti Giovanni ( 1769). Viaggi per l'isola di Cipro e per la Storia e Palestina. Lucca: Jacopo Giusti.

Niglio Olimpia (2007). Akko (Israele). Città del Mediterraneo. In Web Journal on cultural patrimony, I, 2007, p. 98.

Paris Matthew (1259). Chronica Majora. London: ed. by H. Richards Luardscle.

Piccaluga Gabriella (1994). L'interpretazione simbolica della città di Acco attraverso le sue rappresentazioni cartografiche (XIIIXVIII secolo). In Arte Lombarda, I I0/ I I I (3-4).

Piergiovanni Vito (20 I2). Norme, scienza e pratica giuridica tra Genova e l'Occidente medievale e moderno. In Atti delle societc̀ Ligure di Storia Patria, vol. LII, 2, 2012

Prawer Joshua (1972). The Latin Kingdom of Jerusalem. European Colonialism in the Middle Ages. London: M.L. Bulst-Thiele.

Sanudo Marino (I32I). Liber Secretorum Fidelum Crucis. Jerusalem: Massada Press (ed. 1972).

Zerbini Marta, Alessandra Vezzi (2018). II nuovo orizzonte del porto crociato di San Giovanni d'Acri. In Benincasa Fabrizio (a cura di). Seventh International Symposium - Monitoring of Mediterranean Coastal Areas. Problems and Measurement Techniques. Firenze: Firenze University Pre.

\section{Autori}

Cecilia Maria Roberta Luschi, Università degli Studi di Firenze, cecilia.luschi@unifi.it Laura Aiello, Università degli Studi di Firenze, laura.aiello@unifi.it

Per citare questo capitolo: Luschi Cecilia Maria Roberta, Aiello Laura (2020). La ricostruzione storica della città attraverso l'iconografia urbana II caso studio di San Giovanni d'Acri/The historical reconstruction of the city through urban iconography. The case study of St. John of Acre. In Arena A., Arena M., Brandolino R.G., Colistra D., Ginex G., Mediati D., Nucifora S., Raffa P. (a cura di). Connettere. Un disegno per annodare e tessere. Atti del $42^{\circ}$ Convegno Internazionale dei Docenti delle Discipline della Rappresentazione/Connecting. Drawing for weaving relationships. Proceedings of the 42th International Conference of Representation Disciplines Teachers. Milano: FrancoAngeli. PP. 2369-2382. 


\title{
The Historical Reconstruction of the City through Urban Iconography. The Case Ctudy of St. John of Acre
}

\author{
Cecilia Maria Roberta Luschi \\ Laura Aiello
}

\section{Abstract}

The historical reconstruction of the city image through iconography, represents one of the milestones research in the field of urban history. However, such kind studies, over the last thirty years, has been freed from this subsidiarity to achieve an independent research space.

The graphic representation is a powerful means of expression that over the centuries has allowed to leave us traces of great documentary value. The city of Akko, our case study, has a rich urban iconography that allows an interdisciplinary perspective and gives numerous food for thought which is the subject of continuous studies and updates in the different research sectors.

The renewed interest on this site comes down UNESCO site nomination in the 1972, becoming a World Heritage with its Old City. The work of Kesten testifies this new deal of study, in 1993 he is concerned with collecting a lot of studies about Akko. He is offering a modern state-of-the-art picture on which archaeologists, historians and architects still now comparing own work and the new archaeological discoveries.

This grant gives a narrative of the main historical maps and views, going through the analysis of the representation codes to identify the most representative architectural organisms of the city.

Keywords

San Giovanni d'Acri, Akko, urban iconography, historical reconstruction, representation graphic codex.

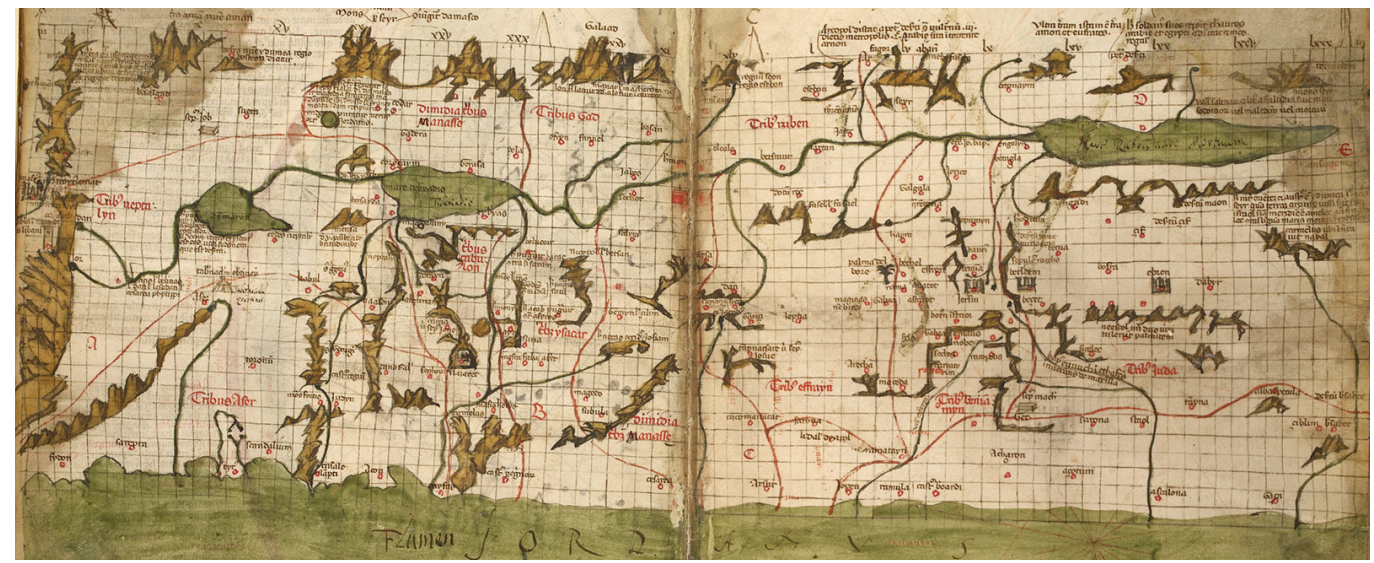


The city has represented a complex and dynamic organism since ever, where its morphological shape looks like a synthesis of different factors: individual and common housing needs, social, religious, economic, political ideas, which, over the centuries they have given different solutions, for several cultural point of view.

To want to reconstruct the image of city reading through the iconographic sources, it means to implement a philological reading that needs to use a depth knowledge about evolutionary mechanisms which implemented the representation codes which adopted for the drafting of the document. To provide the image of a place, it means to do a subjective action anyway that, by structuring itself on a coded language, may necessarily be subject to discretizing action of the person who undertakes the work, even if he be a chronicler, or other kind specialist (geographer, military, landscape painter, miniaturist etc.). The iconographic representation become a direct powerful source, in this context.

The picture in a quickly look could offers us much more data than a narrative description, giving a large information to the researchers that they could not have observed before.

We need codify the representative frames key, therefore it is a relevant phase of study that, if it was correctly conducted, aware us about more information lost otherwise. The research's aims are an interdisciplinary debate necessary to trigger the knowledge processes pursued. The remarkable variety of representations of the city of Akko, today allows to have a vision on very elaborated historical courses. Each specific aspect and each theme addressed to us by the different authors participates in the re-composition of a framework and any kind of elements offer a rich and complex image.

One of the oldest and talk over maps, where it has possible to see the city of Akko, is the Peutingeriana Tabula, we have get a copy of the I2th- I 3th century to date preserved at the Hofbibliothek in Wien and got from an older one and showed the military routes of the Roman Empire. The city of Akko appears as Ptolomaide and is located XXXII miles from Tyre and XX from Thora (today's Zikhron Ya'agov, near the better-known Caesarea).

Thanks to the studies [I] today we can say that the representation of the site falls into the type of double tower icon, common iconology in six variants. Although there is no clear interpretation on the part of the researchers, we can say that exist two reading, or it is a fortified villa with towers, about that we doubt, or it is a posta along the roman cursus publicus. The city of Ptolemaide it is not, however, placed on the coastline but on the early hinterland, where it is believed to be the original route of the Maris road. This location would agree with the finds of Akko Tel of the ancient settlement (fig. I).

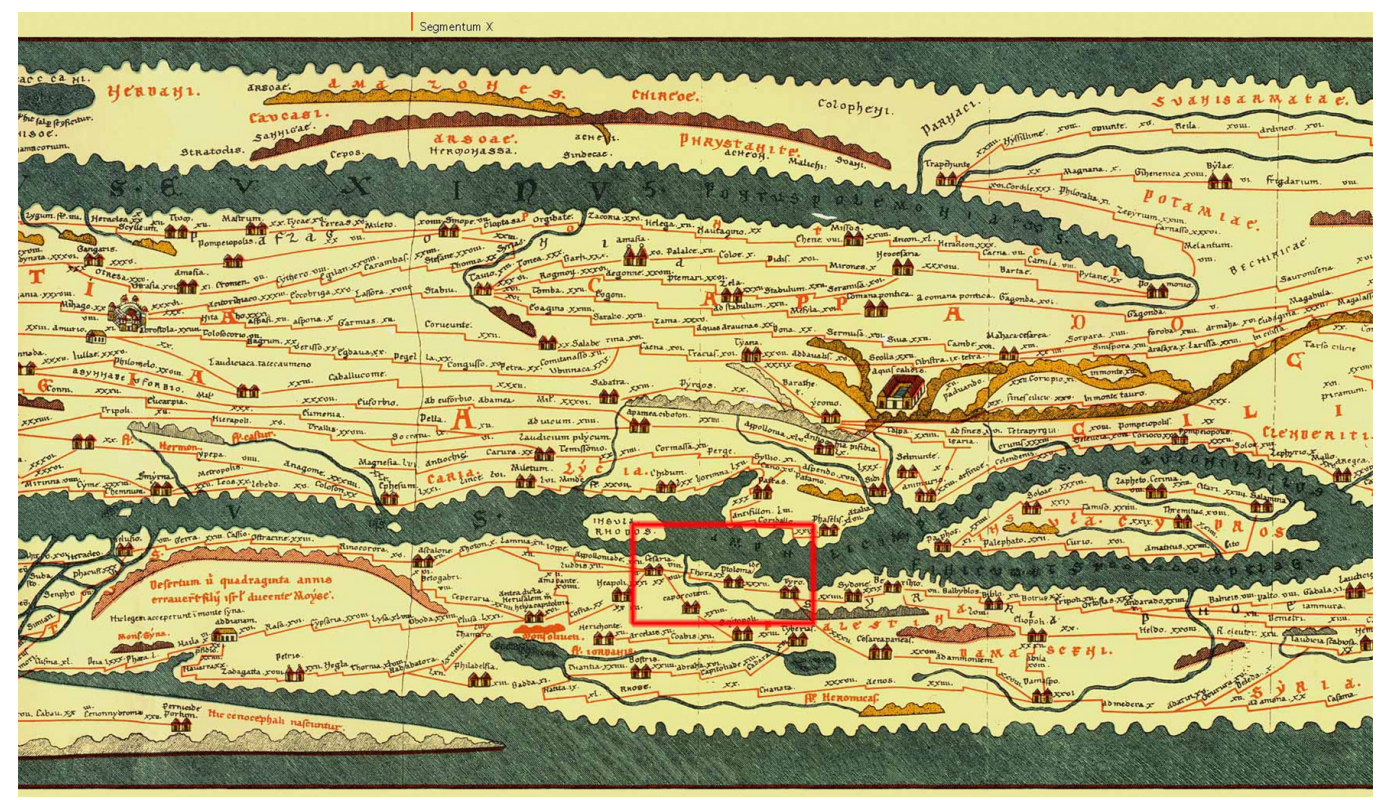


The description of Matthew Paris who in addition offering a descriptive text, in his Cronica Majora [2], and he also drawn a charter of the Holy Land in which the city of Akko is huge proportions than to the other cities. We have two very similar copies of the papers, about we just talk, kept in Cambridge and London at the present (fig. 2).

Analysing the drafting of these, the first observation concerns precisely the extent that is dedicated to the representation of the city. It occupies the central part of the sheet and it seems very large one, if you compared it with the cities of Jerusalem and Tyre, both represented in tiny extensions. It is due surely to the political importance of Akko at the time of writing the document. As you well know, after the fall of Jerusalem in I I 87, the city becomes capital of the Latin Kingdom from I19| to 129|. The Matthew Paris' representation is an ideogram map of the building hierarchies that connoted the places of power of the city, without of reference measures or proportional characters, but its code still seems to be readable today. Examining the two drafts, it is possible observe the each other congruence while finding some different in the writing of the names, as like as to seems to show a different etymological derivation, for example the vile and the cite, which could indicate two different extenders of the cards.

Not being able to appreciate the difference of the graphic technique, we have seen only the web reference, however, we can note that in both representations (fig. 2) the city main fence includes at the upper limit (east side) there is a gate placed in the direction of Da-

Fig. 2. Matthew Paris, Chronica Majora, Itinerary to the Holy Land. Comparison of the two copies dated I240-I253. On the top (a) Cambridge's copy Corpus Christi College Library, MS 26, fiii v-iv

r: below (b) Londra (C)

; below (b) Londra

British Library's copy

Signature Royal MS 14 Hin. fir-5r.The inage of the city of Akko appears much broader when compared to those of the large cities represented in the same map. The representation includes a brief literary description and the toponymy is flanked by descriptive icons that offer a narration that proceeds by parataxis

resting on the main

buildings.
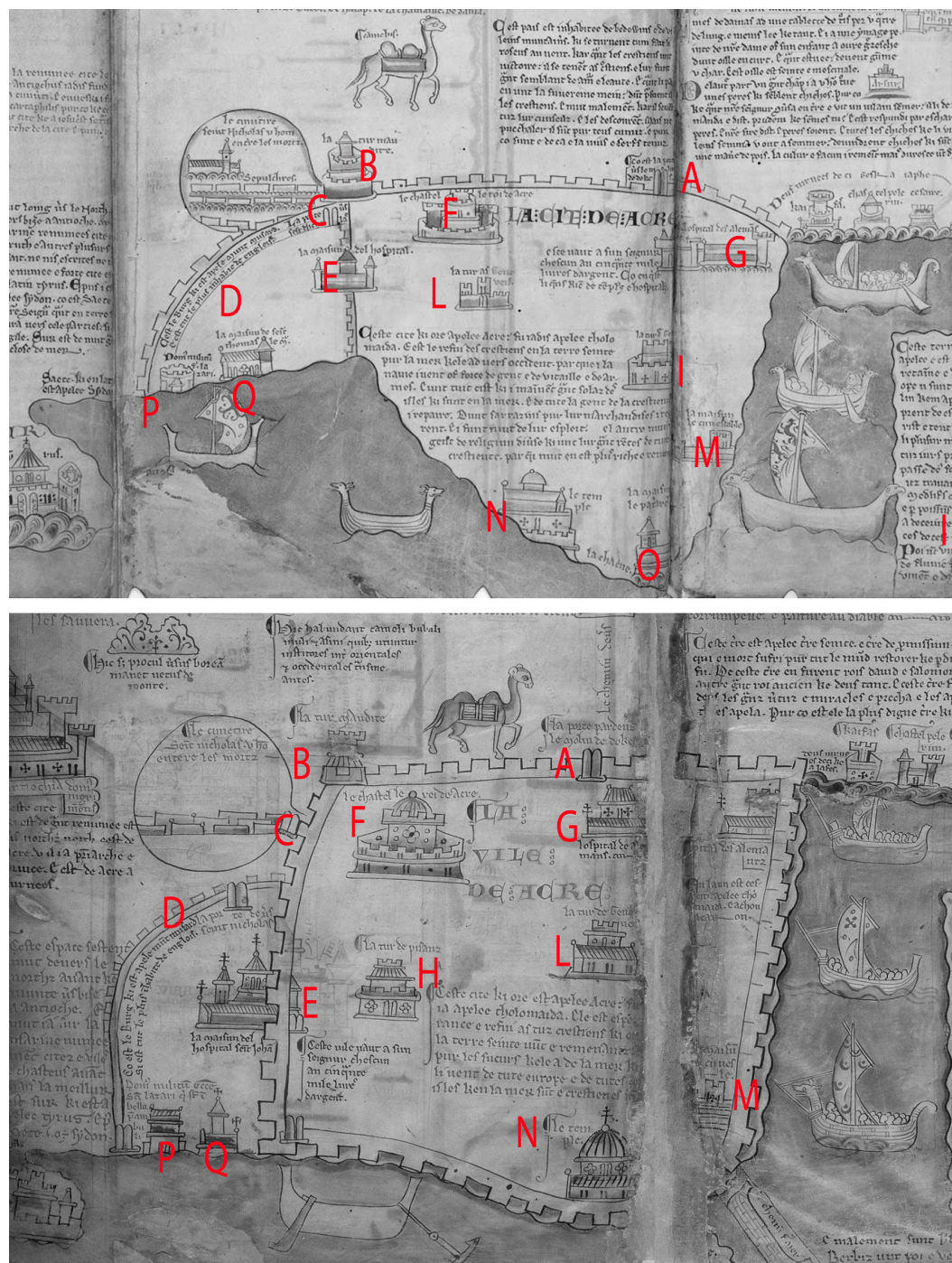
mas [3], Damascus (A). Carrying on counterclockwise you can meet the tur maudite, the cursed tower (B), where the walls bend to east-west to the west a gate opens connecting to the cimetire Sñt Nicholas, as mean the cemetery of St. Nicholas (C) and, even further on, a new portion of walls branches to north from the edge of the city (D) surrounding a district called mũt (mount) mufard, which according to the description was le plus îhabite de englois. Among the buildings of the first wall we recognize the Ospital de Alemans, the Alemanni guesthouse, in the north east (G); the maisun des hospital sñt Joha, the Hospitals' house, straddling the inner walls (E); le chastel le roi de Acre, the castle of the King of Acre, to the North (F); the tur de pisanz, the Pisans' tower, in the middle of the London paper alone $(H)$, it fronted to the south-east by the tower of the Venetians, the tur de vene[****] (L); instead of the Pisans'Tower in the Cambridge's map, you can found the tur S. Gr[****]. We also recognize the temples, the temple $(\mathrm{N})$, represented in both maps as a domed building and the maisũ du cunestable, the house of the constable along the coast (M). In the Cambridge paper we note a singularity as: between the temple and the house of the constable is a building called the maison le patard $(\mathrm{O})$, which, given the call of the name to an ancient money, we could go to identify as the customs of the port. Very near from this location is marked la chaene, the chain, which closed the port itself, an important element reported in some pilgrims' chronicles [4] too. Two other buildings are located in the area of mont mufar. the first, military-style, built close to the ring wall: Dom militu ecce Sĩ Lazari (P) and, from what can be read on the map of Cambridge, the maison de seĩt Thomas le $m$ (Q). Both representations drawn between 1240 and 1253, show a high naval activity in the port. From this the shape the port in not described in morphologic way but with the deployment of the ships. Some parts of boats are arranged perpendicular to the coast (to the right of the drawing) the other in navigation are depicted during the cabotage way. This is interesting because in the 1240-43 years was written the Pisan Portulano Lo compasso da navigare [5], found in Alghero in 1992 and where was described the approach to the port of Acre that seems according to agree the representation of Paris, and we wish remember that he wrote it in $1240-1253$.

Another representation that we have thank to the Vesconte [6], he painted it sixty year later Paris.To these years it is dated his cartography included within the collection Secreta Fidelium Crucis by Torsello [7]. Again we have two different drafts of the same map, one preserved in Oxford and the other in London, made with materials and colours congruent with each other, with toponymy references match, but with a difference in the graphic representation: in the first, compared to that of London, the main buildings are depicted not in the flat plant but offering some volumetric indication to give representation of roofs plan [8].

These maps have been of great importance to those researchers have been involved identifying the Crusader' places. The comparison with the Paris' map allows to confirm the each other relations of the main quarters: the juxtaposition of the Pisa district and the Venetian one $(\mathrm{H}-\mathrm{L})$, most concerned of the port area; the location of the guest house (E) close to the East-West walls and just to the East that of the castle (F). The position of the alemanni (G) near the east ring wall of the city where Paris placed the way to Damascus $(A)$ is confirmed. Less clear, however, is the actual possibility of identifying the house of the cunestable identified by Paris with the arsenal $(M)$ identified by the Vesconte, both located along the coasts south of the Venetian quarter $(L)$. The name of the cursed tower on the corner of the first ring wall (B) remains unchanged (fig. 3).

Between the Vesconte' paper and the modern recognition of main architectural, we can put the view of city in the late 17th century by Gravier d'Ortières [9]. The picture seems dominated by huge ruins (fig. 5), according to an overview from the sea to the city. The ashes of mighty Gothic church of St Andrea ( $X$ ), characterize the extreme headland at sea.

Carrying out a check of all the maps, it is possible to identify the some buildings that in the following centuries keep on the urban structure of Akko and even today, we can mark out it between archaeological finds or vertical remains of the palaces. He represented the old port remains with some boats still inside $(Y)$. The analysis of the view of Gravier, moving from left to right, underline a buildings' curtain with a low flat-roofed, developing itself until intercepts a construction overlooking the coast and covered by the typical dome of mosques, 
Fig. 3. Vesconte, Civitas Sanudo (1321-1323). Digital Collection by the British Lollection by the Brish Library, Londra. the leter coringond re recognized in the Paris charter. It is a real map where a complete plan of the city is presented and underlined with the main buildings drawed in the elevations way with their major characteristic features.

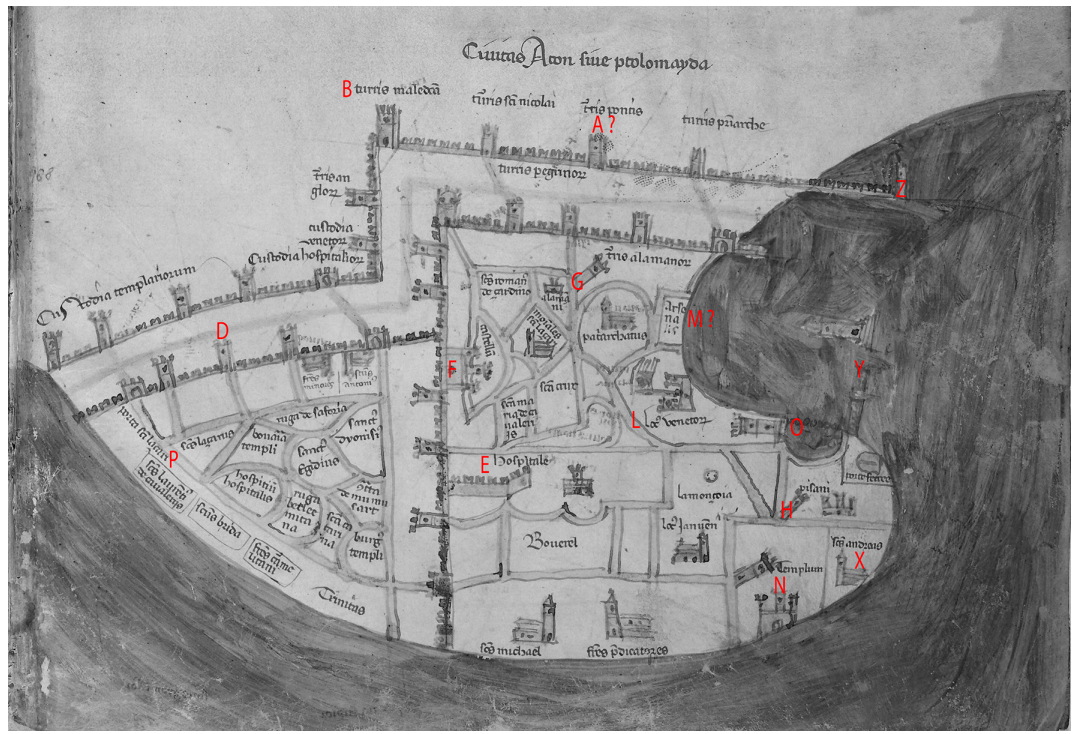

maybe the current mosque of Sinan Basha. If all we said right now is true, it is possible to identify (on left of mosque) the ruins of the Dominican convent on which will be built in 1785 the Khan el-Undan. On the right, an inscription shows Palais du grand maitre, indicating a mighty construction placed in the background. Making a parallel we could identify this building with the castle in the Vesconte' map. As well as that could it be the Citadel of Acre. An imposing tower that could be the tower of the Burj al-Sultan at present, and it can be connect it directly with the Arsenal (M?) in the Vesconte' representation. Three arches seem to follow the site of the former Clarisse convent where now Khan a-Shawarda stands. The view of 1685 , proposes a realistic image of Akko, now almost abandoned and in ruins.

It is interesting to observe how the Picard map of 1630 recovers, in his representation of the Civitas Acon sive Ptolemaida he showed allegedly unrealistic image of the city. However, it is interesting to note how he seems to refer to several iconographic sources: firstly, the Vesconte, whose reference is declared by the same author, secondly, less accredited, he could be just the Paris. The matter of the fact Picard made a kind of axonometry cavalier based on the Vesconte map and added again the naval activity within the port of Akko like have done Paris.

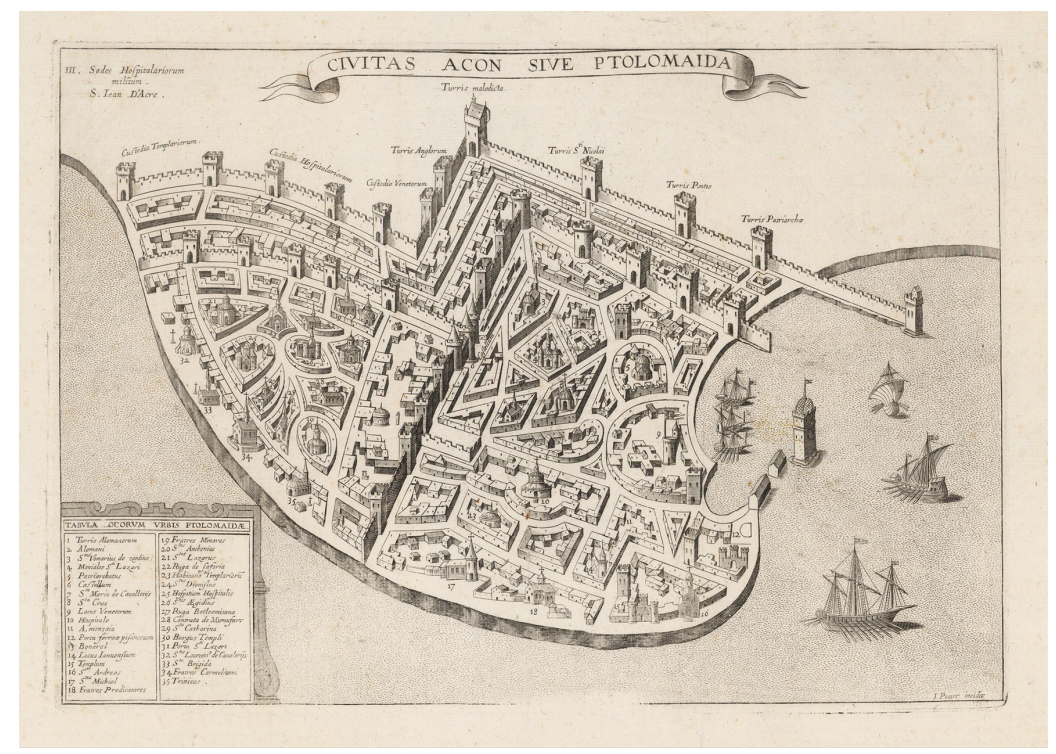

Fig. 4. Picart (engraver) Civitas Acon sive Ptolomaida, 1630.The Eran Laor Cartographic Library of Israel. Map of the city characterized by a referenced list and pseudo-axonometric representation of eminent buildings' most well-groomed elevations. 
Fig. 5. Étienne Gravier, Vue de Saint-lean d'Acre, | 685- | 687, Bibliothèque Nationale de France, département Cartes et plans, GE DD-226 ( 14 RES). The red letters accorded to buildings whic you shall found in the Vesconte map. It is a view from the sea towards the city where a hierarchization is maked, in relation to the size, of the most important buildings.
Regarding to this thinking, we would like to observe a historical question; Pisa prided the rights of chain on the port of Akko, information confirmed by its Portulano, where you read the exactly moves to do be carried out the ingress in the port; on the other hand, we like highlight that Vesconte was a cartographer of the Republic of Genoa and Torsello was a Venetian one.

The geo-political issue says to us clarify the reason why the other maps stay be silence; if we joint the political field of the Maritime Republics and the origin of cartographers, we can find out that Genova and Venezia have no chance of entering in Akko unless permission by Pisan. Hence the passage from the particular to the general in the context's study, recovering peculiar explanatory inputs of the descriptive details, makes possible to develop new traces of unexplored research. Urban iconography in its autonomy afford an important reflection on the places' identification, and in the same time, its interaction with the different research fields still allows us today to reveal new interpretations of the representation codes adopted (think of the presence of the boats and the way of representing them in the different maps).

The observations conducted give us a new research perspectives useful to better clarify both how the port's approach, also analysing the Pisan text Lo compasso da navigare; identifying much more strict way the position of main buildings along the waterfront, which were represented in the old view and compared with the modern urban image. The study is aimed at providing increasingly coherent and credible data regarding the modern city for get us must implement conservation and recovery actions regarding its cultural heritage, but which still has no clear historical structure and stratification.

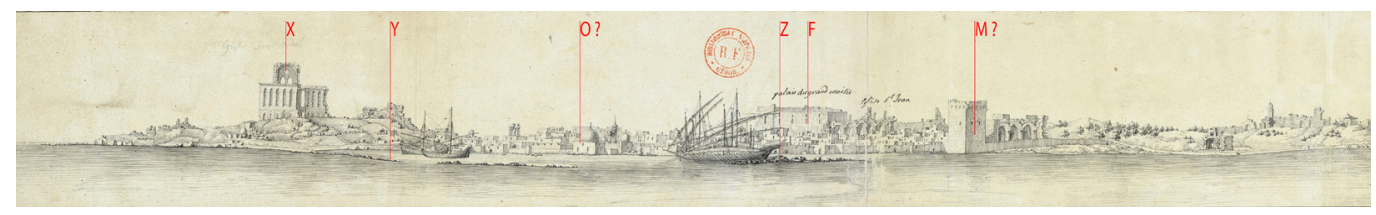

\section{Notes}

[I] See: Bosio 1983, p 109; Carli 2013, pp. 7-25.

[2] Paris, I872-I880 (1259). The Chronic was made public for the first time in 1259 and, says Paris himself, what is inside is material ranging from 1240 to 1253. The first two volumes of the manuscript are located at Corpus Christi College in Cambridge, the third is annexed to his Historia Anglorum, kept in the British Library in London. Much of the work has been made public via the online digitization by the British Library.

[3] Unless stated otherwise, the name indicated refers to the toponym written on the London map.

[4] See: Sanudo, 1972 (I 32 I), n66; DiVitry (1226) in De Sandoli, I983, Vol. III, p. 307

[5] Debanne 20II.

[6] Today it is possible to see the originals thanks to the digitization work of the British Library in London. The collection includes: a world map, Mappamundi, drawn in the style of a nautical chart, five portolan nautical charts of the coasts of Europe and North Africa, a summary map of Eastern Europe and a map of the Holy Land.

[7] Sanudo, 1972 (I 32 I). The work was printed in in Hanover ( 6 | I) edition of Jaques Bongars; some copies of the original manuscripts are now kept in Florence, London and Paris.

[8] This element will be taken up and developed in the seventeenth-century re-editions and especially in the Picard engraving of I 630 which will set an axonometric view of the city, offering the representation of the buildings with the volumetric shape mentioned in the pseudo-axonometric views of the Vesconte.

[9] Étienne Gravier, Vue de Saint-Jean d'Acre, I685-1687, Bibliothèque Nationale de France, département Cartes et plans, GE DD-226 ( 14 RES). 


\section{References}

Bosio Luciano (1983). La Tabula Peutingeriana. Una Descrizione Pittorica del Mondo Antico. Rimini: Maggioli Editore.

Cardini Franco (1933). Studi sulla storia e sull'idea di Crociata. Roma: Jouvence.

Cardini Franco (197I). Le crociate: tra il mito e la storia. Roma: Istituto di cultura nova civitas.

Carli Olivia Sara (20I3). Le 'Vignette' della Tabula Peutingeriana. In Calandra di Roccolino Giacomo, Carli Olivia Sara (a cura di) Antichità immaginate. Engramma 106 maggio 2013.

Cristea Ovidiu (2002). La suprématie maritime à la fin du XIlle siècle:un point de vue de Marino Sanudo Torsello. In Annuario Istituto Romeno di cultura e ricerca umanistica, 4, 2002

De Sandoli Sabino (1983). Itinera Hierosolymitana Crucesignatorum, Vol. III. Jerusalem: Franciscan Printing Press.

Debanne Alessandra (20I I). Lo Compasso de navegare. Edizione del codice Hamilton 396. Bruxelles: Peter Lang.

Fanucci Giovanni Battista (I 8|7). Storia dei tre celebri popoli marittimi dell'Italia. Veneziani, Genovesi, Pisani. E delle loro navigazioni e commerci nei bassi secoli, libro III. Pisa: Francesco Pieraccini editore, pp. 3-7.

Kesten Alex (1993). The old city of Acre. Re-examination report 1993. Acre: Printed by the survey of Israel.

Luschi Cecilia Maria Roberta (2018). Among the archaeologists and the designers: a critical survey of Sant'Andrea of Acre in Israel. In Czasopismo Techniczne, 2018,Vol.I I.

Mariti Giovanni ( 1769). Viaggi per l'isola di Cipro e per la Storia e Palestina. Lucca: Jacopo Giusti.

Niglio Olimpia (2007). Akko (Israele). Città del Mediterraneo. In Web Journal on cultural patrimony, I, 2007, p. 98.

Paris Matthew (1259). Chronica Majora. London: ed. by H. Richards Luardscle.

Piccaluga Gabriella (1994). L'interpretazione simbolica della città di Acco attraverso le sue rappresentazioni cartografiche (XIIIXVIII secolo). In Arte Lombarda, I I0/ I I I (3-4).

Piergiovanni Vito (20 I2). Norme, scienza e pratica giuridica tra Genova e l'Occidente medievale e moderno. In Atti delle societc̀ Ligure di Storia Patria, vol. LII, 2, 2012

Prawer Joshua (1972). The Latin Kingdom of Jerusalem. European Colonialism in the Middle Ages. London: M.L. Bulst-Thiele.

Sanudo Marino (I32I). Liber Secretorum Fidelum Crucis. Jerusalem: Massada Press (ed. 1972).

Zerbini Marta, Alessandra Vezzi (2018). II nuovo orizzonte del porto crociato di San Giovanni d'Acri. In Benincasa Fabrizio (a cura di). Seventh International Symposium - Monitoring of Mediterranean Coastal Areas. Problems and Measurement Techniques. Firenze: Firenze University Pre.

\section{Authors}

Cecilia Maria Roberta Luschi, Università degli Studi di Firenze, cecilia.luschi@unifi.it Laura Aiello, Università degli Studi di Firenze, laura.aiello@unifi.it

To cite this chapter. Luschi Cecilia Maria Roberta, Aiello Laura (2020). La ricostruzione storica della città attraverso l'iconografia urbana II caso studio di San Giovanni d'Acri/The historical reconstruction of the city through urban iconography. The case study of St. John of Acre. In Arena A., Arena M., Brandolino R.G., Colistra D., Ginex G., Mediati D., Nucifora S., Raffa P. (a cura di). Connettere. Un disegno per annodare e tessere. Atti del $42^{\circ}$ Convegno Internazionale dei Docenti delle Discipline della Rappresentazione/Connecting. Drawing for weaving relationships. Proceedings of the 42th International Conference of Representation Disciplines Teachers. Milano: FrancoAngeli, pp. 2369-2382. 